\title{
O VALOR SENTIMENTAL DA COLEÇÃO
}

\author{
LIDIA MOREIRA DOS SANTOS ${ }^{1}$ MÔNICA LIMA DE FARIA² \\ 1Universidade Federal de Pelotas - lidia.santos95@hotmail.com \\ 2Universidade Federal de Pelotas - monicalfaria@gmail.com
}

\begin{abstract}
1.INTRODUÇÃO
Este artigo apresenta um estudo exploratório e teórico sobre o valor do objeto, relacionando as teorias com os objetos já analisados durante a pesquisa maior realizada para o Trabalho de Conclusão de Curso, realizado junto aos cursos de Design Gráfico da Universidade Federal de Pelotas, que tem por objetivo apresentar um estudo sobre a Mauricio de Sousa Produções a partir de sua história e evidenciando sua transformação editorial ao logo de sua trajetória. O seguinte texto corresponde ao capitulo no qual abordamos o valor sentimental que o colecionador possui em relação ao objeto.
\end{abstract}

\section{METODOLOGIA}

Consideramos que este artigo é parte de uma pesquisa mais ampla que está sendo desenvolvida junto com aos cursos de Design da UFPEL, está sendo realizada uma pesquisa qualitativa exploratória, utilizando recursos bibliográficos e documentais para a coleta de dados. O estudo propõe situar o colecionador de quadrinhos em um âmbito teórico, analisando a conexão sentimental que o colecionador possui com o objeto.

\section{RESULTADOS E DISCUSSÃO}

Como já observado durante uma pesquisa histórica e bibliográfica desenvolvida durante a primeira fase do projeto de graduação, a Mauricio de Sousa Produções sempre se preocupou em produzir edições especiais dos seus gibis, sempre ao comemorar alguma data redonda era lançado algum produto promovendo a data e a marca. Atualmente é notável a preocupação da empresa com esse público colecionador, lançando edições históricas e fazendo várias campanhas promocionais para provocar o interesse do leitor nos volumes mais antigos da Turma da Mônica. Um exemplo é a mais nova campanha da Salvat (Figura 1), que lançou uma linha de miniaturas exclusivas de vários personagens da Turma da Mônica, cada miniatura acompanha fichas dos personagens, contando suas primeiras aparições, primeiras publicações, curiosidades, entre outras informações. 


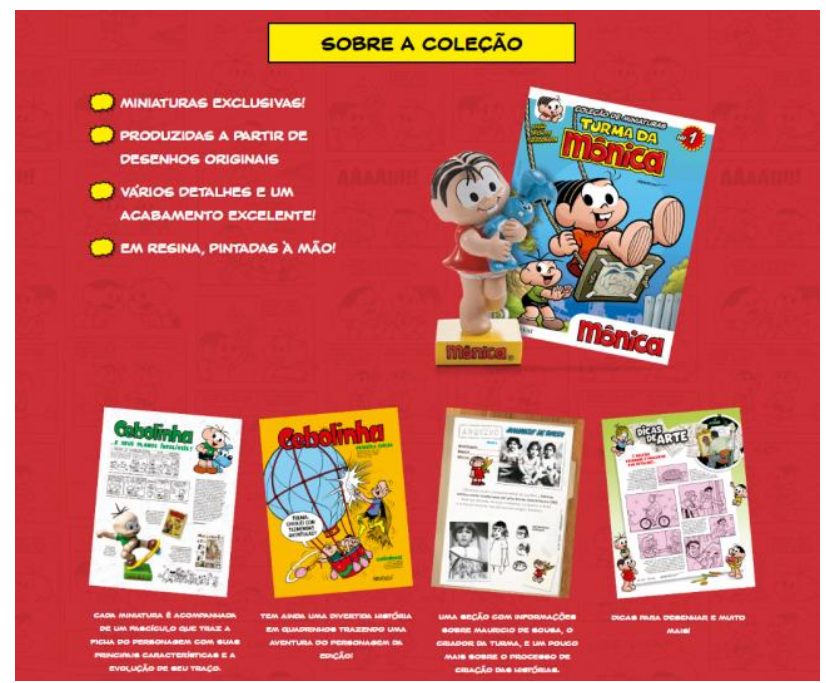

Figura 1: Coleção de miniaturas lançada pela Salvat Fonte: Salvat

Pode-se identificar os consumidores de quadrinhos, em sua maioria, como colecionadores, e o colecionador tem uma relação de prazer com a obtenção de um item relacionado ao seu objeto de desejo. Jean Baudrillard (2008) relaciona o caráter simbólico do objeto como um nível que ultrapassa o caráter funcional, algo que é adquirido não pela sua função mas sim pelo signo que representa, e que simbolicamente adquire vida própria e um significado próprio, consequentemente ignorando sua funcionalidade. Essa relação entre consumidor e objeto pode ser vista como uma função superficial, mantida apenas pelo fator sentimental entre os dois.

O homem é reduzido à incoerência pela coerência de sua projeção estrutural. Em face do objeto funcional o homem torna-se disfuncional, irracional e subjetivo, uma forma vazia e aberta então aos mitos funcionais, às projeções fantasmagóricas ligadas a esta estupefaciente eficiência do mundo (BAUDRILLARD, 2008 p. 63).

Contudo é possível entender que se objeto é adquirido por nível sentimental, ele por conseguinte obtém caráter funcional pois sua função agora se tornar um preenchimento à vida de alguém. De acordo com uma matéria escrita por Daniel Faris $(2014)^{1}$ colecionar objetos é uma prática pré histórica, ela existe desde quando o ser 1 humano começou a guardar mais comida do que ele precisava para sobreviver, desde então viemos coletando e guardando objetos que não precisamos por simples interesses pessoal. Na matéria, Faris (2014) traça as diferenças entre um colecionador e um acumulador: o colecionador sempre tem uma motivação ao colecionar, sendo esses motivos lógicos ou motivos sentimentais; já o acumulador possui uma compulsão em não se desfazer de seus objetos, mesmo que eles não tenham nenhuma função ou valor sentimental. Outra matéria interessante é a de Marcus Ramone (2015) que conta um pouco do comportamento do colecionador de quadrinhos, fala que essa prática, dada como hobby, é algo que pode trazer benefícios, ou não:

\footnotetext{
${ }^{1}$ Disponível em:<http://www.zmescience.com/other/feature-post/problem-using-psychology-explaincollecting/> . Acesso em: 16 de junho de 2016.
} 
À luz da psicologia e da sociologia, os fãs de quadrinhos costumam render um rico debate que tanto poderia enquadrá-los na categoria dos que têm dificuldades no convívio em sociedade e sofrem de conflitos íntimos por causa de uma suposta dependência, quanto dentre aqueles que fazem da leitura e do colecionismo de gibis e artigos afins uma prática bastante saudável, muitas vezes estimulada em tratamentos psicológicos ou atividades educacionais (RAMONE, 2015) ${ }^{2}$.

A partir de um depoimentos do psicólogo Leandro Kruszielski para o repórter Marcus Ramone (2015) "Um adulto que lê apenas (e muito) Turma da Mônica pode realmente ter problemas com a maturidade ou somente estar se divertindo, lembrando seus bons momentos da infância".

A conexão que o leitor tem com o quadrinho é extremamente sensitiva, o quadrinho permite e auxilia a partir da imaginação o ingresso em universo incomum do abordado em um filme ou em um livro, através do grafismo é possível reproduzir sentimentos diversos e levantar temáticas diferenciadas.

A matéria-prima dos quadrinhos, como a de qualquer produto no interior das artes plásticas, é o grafismo- o grafismo que nasce do sonho, que nasce do desejo, que nasce da paixão, que nasce de nossa mais profunda humanidade. Por isso, os quadrinhos, em sendo bons, podem seduzir, podem ser apaixonantes. E podem, amorosamente ou não, levar à reflexão. Com certeza, para qualquer museu imaginário criado pelo espírito humano, sempre haverá lugar para as histórias-em-quadrinhos (CIRNE, 2000. p 218).

\section{CONCLUSÃO}

A pesquisa ainda não chegou na sua etapa final mas podemos observar o comportamento do colecionador como um comportamento cotidiano, que todos temos diante objetos diferentes, se transformando assim objetos de desejos para cada tipo de consumidor.

\section{REFERÊNCIAS BIBLIOGRÁFICAS}

BAUDRILLARD, Jean. O Sistema dos Objetos. São Paulo: Perspectiva, 2008. 2 Disponível em: <http://www.universohq.com/materias/aspectos-comportamentais-doscolecionadores-de-quadrinhos-nobrasil/> . Acesso em: 16 de junho de 2016.

CIRNE, Moacy. Quadrinhos, sedução e paixão. Rio de Janeiro: Vozes, 2000.

FARIS, Daniel. The Problem with Using Psychology to Explain Collecting, 2014. ZME Science. Disponível em: <http://www.zmescience.com/other/feature-post/problem-usingpsychology-explain-colle cting/> . Acesso em: 16 de junho de 2016.

\footnotetext{
${ }^{2}$ Disponível em: <http://www.universohq.com/materias/aspectos-comportamentais-dos-colecionadores-dequadrinhos-nobrasil/> . Acesso em: 16 de junho de 2016.
} 
RAMONE, Marcus. Aspectos comportamentais dos colecionadores de quadrinhos no Brasil, 2015. UNIVERSO HQ. Disponível em:

<http://www.universohq.com/materias/aspectos-comportamentais-dos-colecionadores-d equadrinhos-no-brasil/s . Acesso em: 16 de junho de 2016. 